\title{
One-pot regioselective synthesis of new 5-(arylsulfonylamino)imidazo[2,1-b]thiazoles
}

\author{
Valery Y. Serykh, Gulnur N. Chernysheva, \\ Evgeniy V. Kondrashov, Aleksandr V. Vashchenko, Vladimir I. Smirnov, \\ and Igor B. Rozentsveig*
}

A.E. Favorsky Irkutsk Institute of Chemistry, Siberian Branch, Russian Academy of Sciences, 1 Favorsky Street, Irkutsk 664033, Russia

E-mail: iroz@irioch.irk.ru

DOI: $\underline{\text { http://dx.doi.org/10.3998/ark.5550190.p009.380 }}$

\begin{abstract}
$N$-(2,2-Dichloro-2-phenylethylidene)-4-chlorobenzenesulfonamide reacts with 2-aminothiazoles to give products of nucleophilic addition in good yields. The adducts are cyclized into the unexpected 5-(arylsulfonyl)amino-6-phenylimidazo[2,1-b]thiazoles in 70-75\% yield; whereas the anticipated isomeric 6-(arylsulfonyl)amino-5-phenylimidazo[2,1- $b]$ thiazoles were not observed.
\end{abstract}

Keywords: Imines, nucleophilic addition, cyclization, imidazo[2,1-b]thiazoles, sulfonamides

\section{Introduction}

Owing to the activated electron-deficient azomethine group in their structures, $N$-acyl- and $N$-sulfonyl $\alpha$-halo imines react efficiently with O-, N-, S-nucleophiles, aromatics and heteroaromatics to afford various functionalized acyclic and heterocyclic amide and sulfonamide derivatives. $^{1-12}$ Moreover, besides the carbon atom of azomethine group, $\alpha$-haloimines contain another electrophilic reactive site, namely the carbon atom of the polyhalomethyl group. Thus, these compounds are promising dielectrophiles that can be used as key reagents in the preparation of amidines, ${ }^{7}$ biologically active amino acids, ${ }^{9}$ and heterocycles. ${ }^{8,10-12}$

$\mathrm{N}$-Sulfonyl-substituted phenyldichloroacetaldimines of the type $\mathbf{1}$ are key representatives of activated electrophilic imines, that are available through previously developed methods based on free-radical reaction of $N, N$-dichlorosulfonamides with phenylacetylene (Scheme 1). ${ }^{13,14}$ Until now, no alternative syntheses to $N$-(2,2-dichloro-2-phenylethylidene)arenesulfonamides of type $\mathbf{1}$ have been developed. 


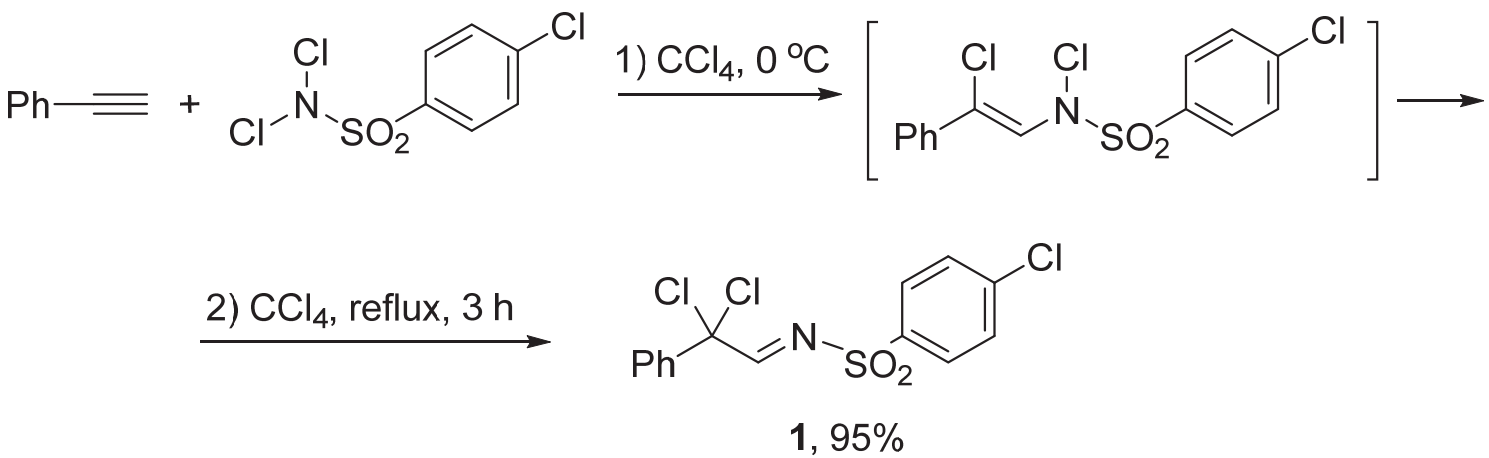

Scheme 1. Synthesis of 4-chloro- $N$-(2,2-dichloro-2-phenylethylidene)benzenesulfonamide 1.

The formation of imine $\mathbf{1}$ is a one-pot free-radical process proceeding via unstable intermediate $N$-chloro- $N$-vinyl adducts (see Scheme 1). The reaction is performed under argon in $\mathrm{CCl}_{4}$. Reagent addition order is important: when $\mathrm{N}, \mathrm{N}$-dichloroamide is added to a solution of phenylacetylene, the yields of imines are substantially higher than when the reagents are mixed in the reverse order (90-95 vs. 40-64\%). The reaction has an induction period after which it proceeds with notable self-heating. It is important that the reaction mixture is cooled during the exotherm and is heated for $3 \mathrm{~h}$ after the exothermic process has been complete. ${ }^{14}$ Imine $\mathbf{1}$ is precipitated upon cooling of the reaction mixture and can be readily separated and used for further synthetic transformations without additional purification.

Imine 1 reacts with nucleophiles on the carbon atom of the activated azomethine groups, ${ }^{1,8-11}$ and also can act as a dielectrophile, successively involving the azomethine moiety and polyhalomethyl fragment in the process. ${ }^{8-12}$ Based on these reactions, the synthesis of heterocycles, containing the arylsulfonamide pharmacophore, has been developed. ${ }^{8-12}$ In the present work we have studied the reaction of imine 1 with a range of 2-amino-4,5-diarylthiazoles to elaborate a method for the synthesis of sulfonylamino-substituted imidazo[2,1$b]$ thiazoles.

Worthy of note is that imidazo[2,1-b]thiazoles exhibit a wide range of biological activity. For example, imidazo[2,1-b]thiazoles are inhibitors of acetylcholine esterase ${ }^{15}$ and other enzymes, ${ }^{16,17}$ as well as receptor inhibitors. ${ }^{18}$ They also demonstrate diuretic, ${ }^{19}$ antitumour, ${ }^{20-23}$ antimicrobial, ${ }^{24,25}$ fungicidal $^{26}$ and antihelmintic ${ }^{27}$ activity.

The most efficient method to obtain imidazo[2,1-b]thiazoles is the conversion of 2-aminothiazole with $\alpha$-halocarbonyl compounds or propargylbromide (Scheme 2). ${ }^{28}$ Imidazo[2,1-b]thiazoles can also be prepared via the reaction of $\alpha$-halocarbonyl compounds with 2-mercaptoimidazoles. ${ }^{28}$ The most promising approach to amino-substituted imidazo[2,1$b]$ thiazoles is based on multicomponent reactions of 2-aminothiazole, isocyanides, and aldehydes or 2-bromoacetophenone derivatives, aromatic aldehydes, thiourea, and isocyanides (Scheme 2). ${ }^{28,29}$ 


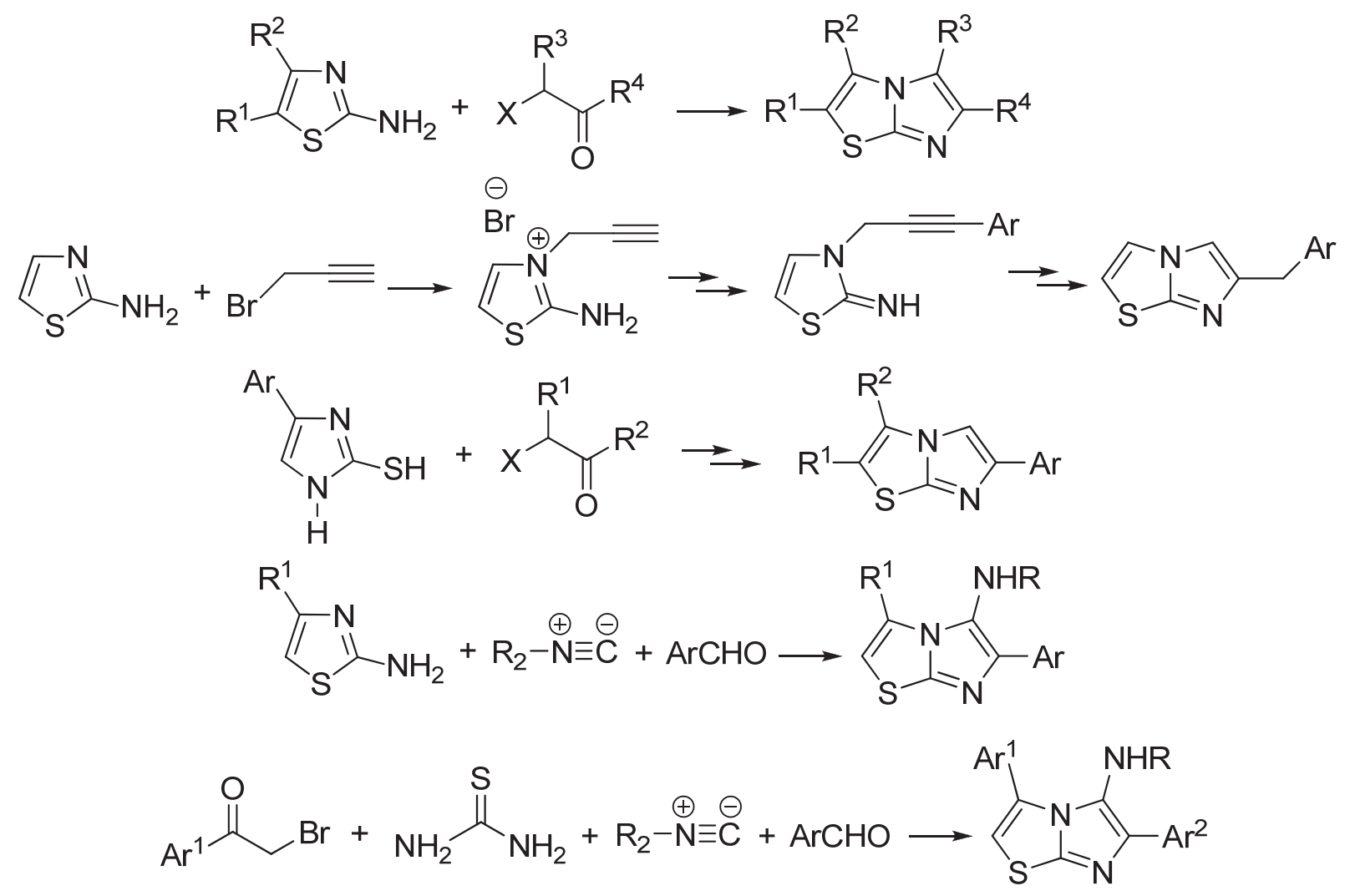

Scheme 2. Methods for the preparation of imidazo[2,1- $b]$ thiazoles. ${ }^{28,29}$

However, with the exception of our previous report, ${ }^{11}$ the literature contains no information on the preparation of $N$-sulfonylamino-substituted derivatives of imidazo[2,1- $b]$ thiazole.

\section{Results and Discussion}

4,5-Diaryl-substituted 2-aminothiazoles $\mathbf{3 a}$ and $\mathbf{3 b}$, required for the directed synthesis of the target imidazothiazole derivatives, were prepared according to Scheme 3. The first step was the synthesis of sulfonylimine $\mathbf{1}$ followed by $\mathrm{C}$-amidoalkylation of anisole or thioanisole. Next, the amidoalkylation products $\mathbf{2 a}$ and $\mathbf{2 b}$ were reacted with thiourea (Scheme 3). Anisole derivatives $\mathbf{2 a}$ and 3a were previously prepared according to this protocol. ${ }^{30}$ The corresponding thioanisole derivatives $\mathbf{2 b}$ and $\mathbf{3 b}$ were synthesized during the present work and have not been previously described.

C-Amidoalkylation of thioanisole was more difficult than the analogous reaction of anisole. Anisole reacts with imine $\mathbf{1}$ in the presence of boron trifluoride etherate. ${ }^{1}$ Unfortunately, under the same conditions thioanisole gave no C-amidoalkylation product $\mathbf{2 b}$. Apparently, $\mathrm{BF}_{3}$ affords a stable, poorly nucleophilic and non-reactive complex with thioanisole. 
We have found that compounds $\mathbf{2} \mathbf{a}$ and $\mathbf{2} \mathbf{b}$ are produced in satisfactory yield in the presence of $\mathrm{H}_{2} \mathrm{SO}_{4} / \mathrm{P}_{4} \mathrm{O}_{10}$ mixture. When $\mathrm{H}_{2} \mathrm{SO}_{4}$ is employed without $\mathrm{P}_{4} \mathrm{O}_{10}$ or oleum as a strong acid, the yield of amidoalkylated derivatives $\mathbf{2 a}$ and $\mathbf{2} \mathbf{b}$ was significantly lower.

The reaction proceeded at room temperature under vigorous stirring. An excess of aromatic substrate contributes to an increased yield of amidoalkylated products $\mathbf{2 a}$ and $\mathbf{2 b}$. Substitution was directed to the para-position and the ortho- or meta-isomeric products were not observed.

It can be assumed that, in the presence of $\mathrm{H}_{2} \mathrm{SO}_{4}$ or oleum, anisole and thioanisole are deactivated due to sulfonation. However, the $\mathrm{H}_{2} \mathrm{SO}_{4} / \mathrm{P}_{4} \mathrm{O}_{10}$ combination was an effective protonating medium that readily promoted the formation for sulfonamidoalkyl cations, key intermediates of $\mathrm{C}$-amidoalkylation; whereas the sulfonation side reaction was probably less favourable in the $\mathrm{H}_{2} \mathrm{SO}_{4} / \mathrm{P}_{4} \mathrm{O}_{10}$ mixture.<smiles>Cc1ccccc1</smiles><smiles>[18O][18O][18Os]</smiles>
$\mathrm{CCl}_{4}, 3-5 \mathrm{~h}$ 1 XMe<smiles>Cc1ccc(C(NS(=O)(=O)c2ccc(Cl)cc2)C(Cl)(Cl)c2ccccc2)cc1</smiles><smiles>Cc1ccc(C(NS(=O)(=O)c2ccc(Cl)cc2)C(Cl)(Cl)c2ccccc2)cc1</smiles>

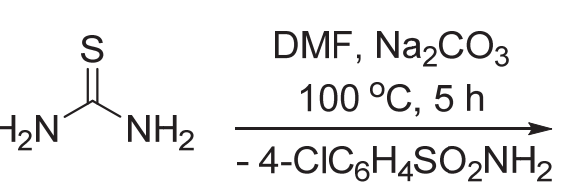

$-\mathrm{HCl}$<smiles>Cc1ccc(-c2sc(N)nc2-c2ccccc2)cc1</smiles>

$3 a, 73 \%$

$3 b, 87 \%$

Scheme 3. Synthesis of compounds $\mathbf{2 a}$ and $\mathbf{2 b}$, and aminothiazoles $\mathbf{3 a}$ and $\mathbf{3 b}$.

4,5-Diaryl-2-aminothiazoles $\mathbf{3} \mathbf{a}$ and $\mathbf{3 b}$ are probably formed via intermediate chloroaziridines A, followed by the ring-opening accompanied by chlorine migration to furnish isomeric imines B. The latter can exist as the tautomeric enamide $\mathbf{C}$. They are able to give intermediate adduct $\mathbf{D}$ with thiourea and heterocyclic derivative $\mathbf{E}$ followed by aromatization owing to elimination of the sulfonamide moiety, as shown in Scheme 4.

In the present investigation, we did not isolate intermediate structures $\mathbf{A}, \mathbf{B}$, and $\mathbf{C}$. However, the proposed pathway for formation of aminothiazoles $\mathbf{3 a}$ and $\mathbf{3 b}$ is in agreement with previously published results regarding formation of the similar chloroaziridine from $N$-[1-(4-methylphenyl)2-phenyl-2,2-dichloroethyl]-4-chlorobenzenesulfonamide ${ }^{7}$ and synthesis of enamide $\mathbf{C}$ from anisole derivative $\mathbf{2 a}$ occurs in the absence of thiourea at room temperature. ${ }^{8}$ 
Synthesized compounds $\mathbf{3 a}$ and $\mathbf{3 b}$ were further investigated in the reaction with imine $\mathbf{1}$. It has been found that the process results in the formation of previously unknown adducts $\mathbf{4 a}$ and 4b (Scheme 5).

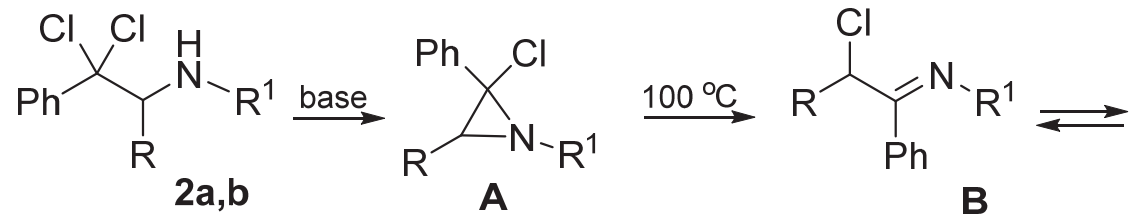

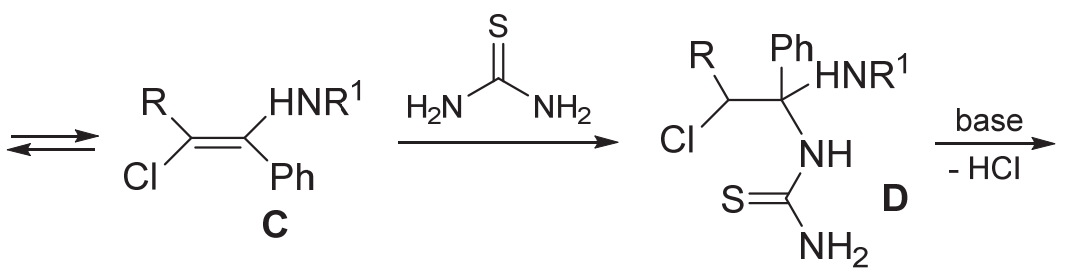<smiles>[R16]c1sc(N)nc1-c1ccccc1</smiles>

$$
\begin{gathered}
\mathrm{R}^{1}=4-\mathrm{ClC}_{6} \mathrm{H}_{4} \mathrm{SO}_{2}, \mathrm{R}=4-\mathrm{MeXC}_{6} \mathrm{H}_{4}, \\
\mathrm{X}=\mathrm{O}(\mathbf{a}), \mathrm{S} \text { (b) }
\end{gathered}
$$

Scheme 4. A possible route to the formation of the 2-amino-4,5-diarylthiazoles $\mathbf{3 a}$ and $\mathbf{3 b}$.
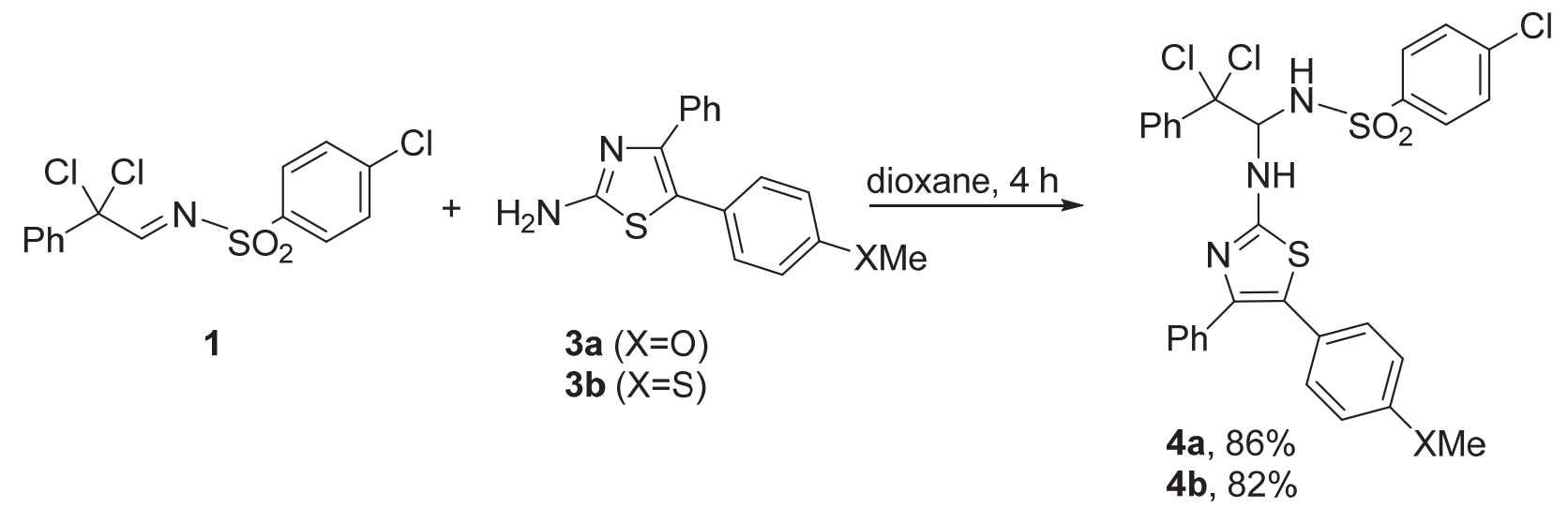

Scheme 5. Formation of adducts $\mathbf{4 a}$ and $\mathbf{4 b}$ in the reaction of sulfonylimine $\mathbf{1}$ with aminothiazoles $\mathbf{3} \mathbf{a}$ and $\mathbf{3 b}$, respectively.

Maximum yields of adducts $\mathbf{4 a}$ and $\mathbf{4 b}$ have been achieved in dioxane. The formation of these adducts occurs without heating in the absence of catalysts and this was tentatively attributed to the high electrophilicity of the activated azomethine group of imine $\mathbf{1}$. 
The formation of adducts $\mathbf{4 a}$ and $\mathbf{4 b}$ was confirmed by spectroscopic analysis. The ${ }^{1} \mathrm{H}$ and ${ }^{13} \mathrm{C}$ NMR spectra of compounds $\mathbf{4 a}$ and $\mathbf{4 b}$ were in agreement with the proposed structures. The resonances due to the NH-CH-NH fragment, the double doublet at 6.46-6.48 ppm, corresponding to the $\mathrm{CH}$ group, as well as two doublets at 8.17-8.24 and 8.93-8.95 ppm, corresponding to $\mathrm{NH}$ groups with a coupling constant of $9.5-9.8 \mathrm{~Hz}$, are symptomatic for these adducts.

Further heterocyclization of compounds $\mathbf{4 a}$ and $\mathbf{4 b}$ was carried out in the presence of base, but this reaction unexpectedly gave 5-(arylsulfonyl)amino-6-phenylimidazo[2,1-b]thiazoles 5a and $\mathbf{5 b}$, respectively; whereas the anticipated isomeric derivatives, 6-(arylsulphonyl)amino-5phenylimidazo[2,1-b]thiazoles $\mathbf{6 a}$ and $\mathbf{6 b}$, were not observed (Scheme 6).

$\mathrm{NaOH}$ in dioxane was the most efficient combination for the preparation of compounds $5 \mathbf{a}$ and $\mathbf{5 b}$ via a two-stage one-pot method without isolation of intermediate adducts $\mathbf{4 a}$ and $\mathbf{4 b}$ (Scheme 7).

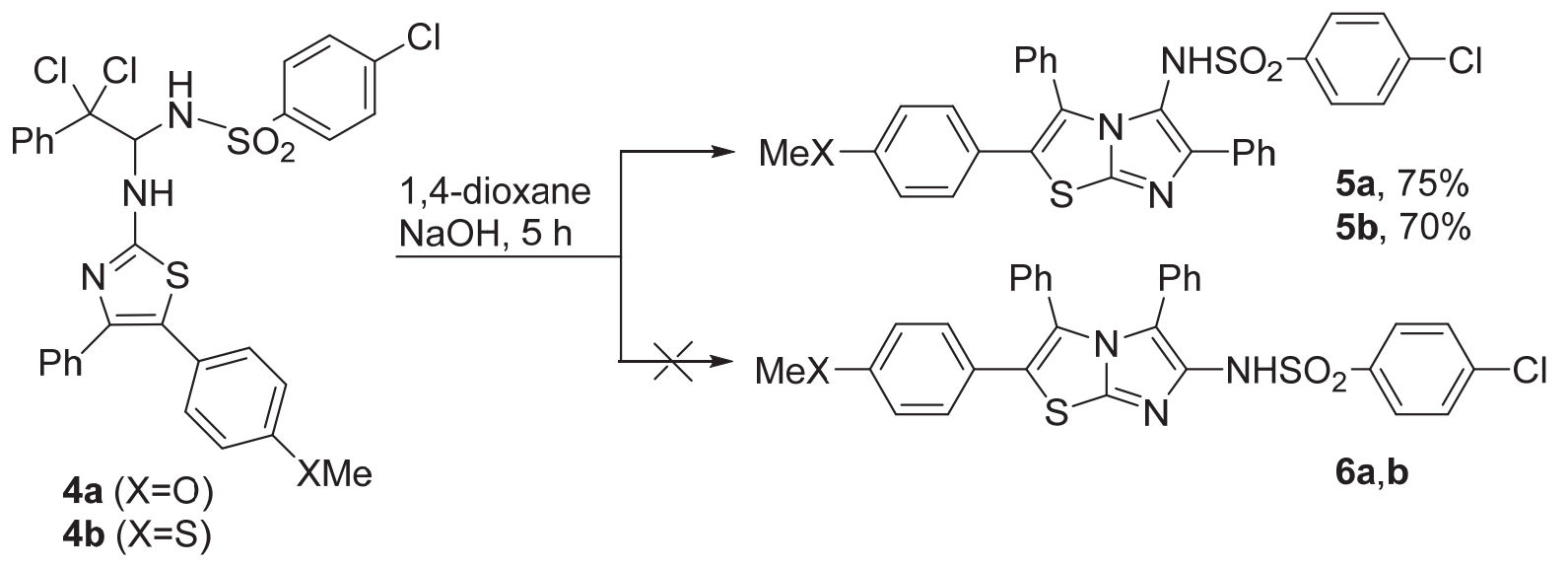

Scheme 6. Heterocyclization of adducts 4 into 5-sulfonylaminoimidazo[2,1-b]thiazoles 5.

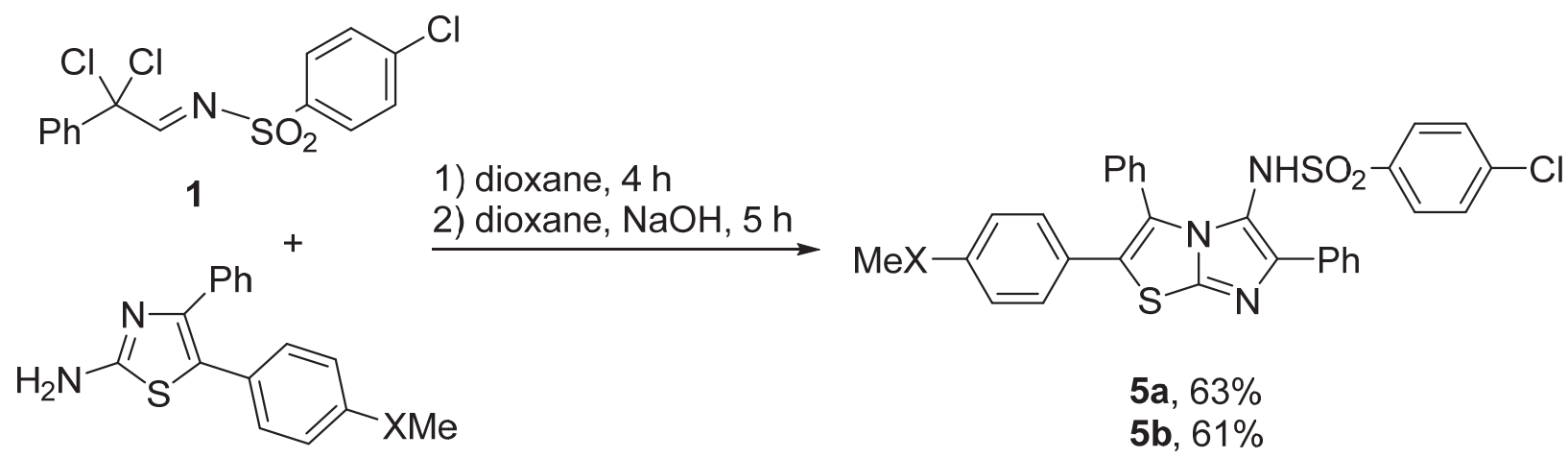

$3 \mathbf{a}(X=0)$

$3 \mathbf{b}(X=S)$

Scheme 7. Two-stage one-pot synthesis of imidazo[2,1-b]thiazoles $\mathbf{5 a}$ and $\mathbf{5 b}$. 
A possible reaction pathway leading to the formation of compounds $\mathbf{5}$ involves heterocyclization of adducts $\mathbf{4}$ into intermediate imidazothiazoles $\mathbf{6}$, which undergo further isomerization into the final compounds according to the Dimroth rearrangement (Scheme 8).
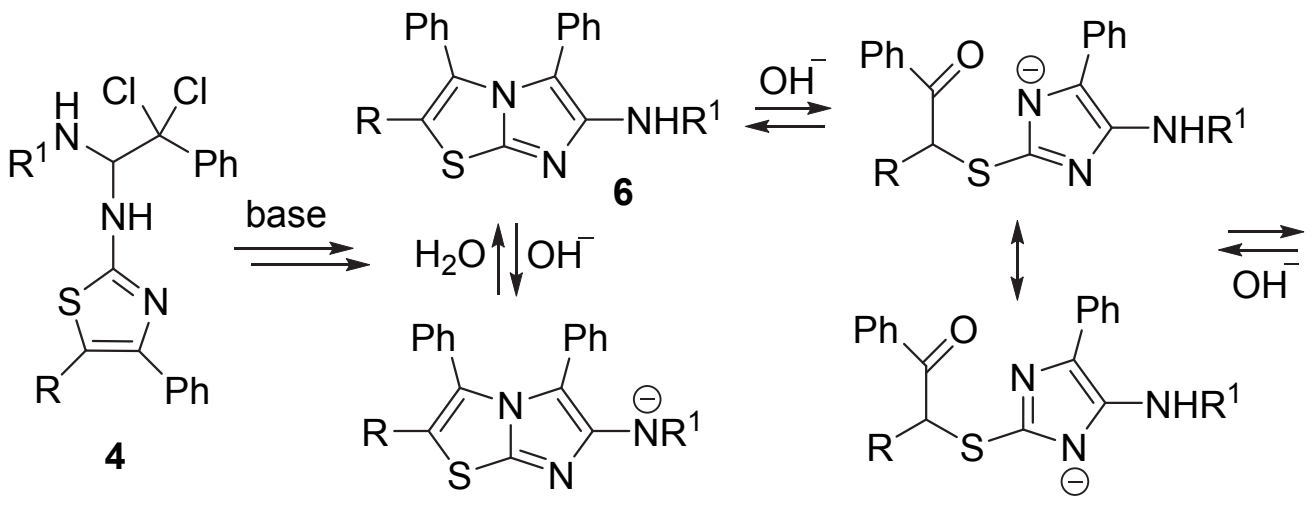<smiles>[R]Nc1c(-c2ccccc2)nc2sc([R])c(-c3ccccc3)n12</smiles>

Scheme 8. A possible pathway for the formation of imidazo[2,1-b]thiazoles 5 via isomeric derivatives 6.

To rationalize the selective formation of the 5-amino-substituted derivatives $\mathbf{5}$, ab initio and DFT methods were used to model the structures 5 and $\mathbf{6}$ (Table 1 and 2), and the relative energies of the 5- and 6-amino-substituted derivatives was estimated.

With an unsubstituted amino group in the imidazothiazole structure (Table 1, entries 1 and 4 ), the 6-amino isomer was energetically preferred by $2.8-3.2 \mathrm{kcal} / \mathrm{mol}$. However, with a strong electron-withdrawing substituent at the exocyclic nitrogen atom, the energy difference between the isomers either disapppeared (according to MP2, Table 1, entries 2 and 3) or was inversed (according to B3LYP, Table 1, entries 5 and 6).

Bearing in mind that $\mathrm{N}$-sulfonyl-substituted aminoimidazothiazoles are potent $\mathrm{NH}$-acids, and the reaction was carried out in the presence of strong base $(\mathrm{NaOH})$, it was logical to suggest that in the reaction mixtures the products existed as their corresponding anions. Modeling the corresponding anions (Table 2) showed that 5-sulfonylamino-substituted imidazothiazoles were significantly preferred $(6-8 \mathrm{kcal} / \mathrm{mol})$, compared to 6-substituted isomers. 
Table 1. Relative energies of neutral molecules in gas phase at completely optimized geometries, $\mathrm{kcal} / \mathrm{mol}$

\begin{tabular}{|c|c|c|c|c|c|}
\hline & & & & ino isomer & 5-amino isomer \\
\hline Entry & $\mathrm{R}$ & $\mathrm{R}^{1}$ & $\mathrm{R}^{2}$ & & \\
\hline \multicolumn{6}{|c|}{$\mathrm{MP} 2 / 6-311+\mathrm{G}(\mathrm{d}, \mathrm{p})^{\mathrm{a}}$} \\
\hline 1 & $\mathrm{H}$ & $\mathrm{H}$ & $\mathrm{H}$ & $\mathbf{0}$ & 2.81 \\
\hline 2 & $4-\mathrm{OMeC}_{6} \mathrm{H}_{4}$ & $4-\mathrm{ClC}_{6} \mathrm{H}_{4} \mathrm{SO}_{2}$ & $\mathrm{Ph}$ & 0.01 & $\mathbf{0}$ \\
\hline 3 & $4-\mathrm{SMeC}_{6} \mathrm{H}_{4}$ & 4- $\mathrm{ClC}_{6} \mathrm{H}_{4} \mathrm{SO}_{2}$ & $\mathrm{Ph}$ & $\mathbf{0}$ & 0.06 \\
\hline \multicolumn{6}{|c|}{$\mathrm{B} 3 \mathrm{LYP} / 6-311+\mathrm{G}(\mathrm{d}, \mathrm{p})+\mathrm{ZPE}^{\mathrm{b}}$} \\
\hline 4 & $\mathrm{H}$ & $\mathrm{H}$ & $\mathrm{H}$ & $\mathbf{0}$ & 3.26 \\
\hline 5 & $4-\mathrm{OMeC}_{6} \mathrm{H}_{4}$ & $4-\mathrm{ClC}_{6} \mathrm{H}_{4} \mathrm{SO}_{2}$ & $\mathrm{Ph}$ & 2.56 & $\mathbf{0}$ \\
\hline 6 & $4-\mathrm{SMeC}_{6} \mathrm{H}_{4}$ & 4- $\mathrm{ClC}_{6} \mathrm{H}_{4} \mathrm{SO}_{2}$ & $\mathrm{Ph}$ & 2.55 & $\mathbf{0}$ \\
\hline
\end{tabular}

${ }^{\text {a }}$ MP2 calculations were performed using the Firefly QC package ${ }^{31}$ which is partially based on Gamess US source code. ${ }^{32}$

${ }^{\mathrm{b}}$ DFT calculations were performed using the Gaussian 09 program package. ${ }^{33}$

Table 2. Relative energies of anions in gas phase at completely optimized geometries, $\mathrm{kcal} / \mathrm{mol}$

\begin{tabular}{|c|c|c|c|c|}
\hline \multirow[b]{2}{*}{ Entry } & \multirow[b]{2}{*}{$\mathrm{R}$} & \multirow[b]{2}{*}{$\mathrm{R}^{2}$} & hino isomer & 5-amino isomer \\
\hline & & & & \\
\hline \multicolumn{5}{|c|}{$\mathrm{MP} 2 / 6-311+\mathrm{G}(\mathrm{d}, \mathrm{p})$} \\
\hline 1 & $4-\mathrm{OMeC}_{6} \mathrm{H}_{4}$ & $4-\mathrm{ClC}_{6} \mathrm{H}_{4} \mathrm{SO}_{2}$ & 7.92 & $\mathbf{0}$ \\
\hline 2 & $4-\mathrm{SMeC}_{6} \mathrm{H}_{4}$ & $4-\mathrm{ClC}_{6} \mathrm{H}_{4} \mathrm{SO}_{2}$ & 8.11 & $\mathbf{0}$ \\
\hline \multicolumn{5}{|c|}{$\mathrm{B} 3 \mathrm{LYP} / 6-311+\mathrm{G}(\mathrm{d}, \mathrm{p})+\mathrm{ZPE}$} \\
\hline 3 & $4-\mathrm{OMeC}_{6} \mathrm{H}_{4}$ & $4-\mathrm{ClC}_{6} \mathrm{H}_{4} \mathrm{SO}_{2}$ & 5.71 & $\mathbf{0}$ \\
\hline 4 & $4-\mathrm{SMeC}_{6} \mathrm{H}_{4}$ & $4-\mathrm{ClC}_{6} \mathrm{H}_{4} \mathrm{SO}_{2}$ & 5.68 & $\mathbf{0}$ \\
\hline
\end{tabular}

Taking into account the structures of $\mathbf{5 a}$ and $\mathbf{5 b}$ obtained by MP2 calculations, one can see that sulfonamide aryl group and the 6-aryl substituent of the imidazothiazole are positioned one 
above the other in almost parallel planes with a distance of 3.1-3.2 $\AA$ between them, resulting from intramolecular $\pi$ stacking. We analysed structure 5a by AIMALL program ${ }^{34}$ according Bader's quantum theory of atoms in molecules. ${ }^{35}$ The wavefunction for the AIM analysis was obtained using a Gaussian ${ }^{33}$ program at the MP2/6-311++G** level. Fortuitously, we were able to identify 7 critical points located between the benzene rings ( 2 bond-critical points with electronic density $\rho(\mathrm{r})=7.8^{*} 10^{-3}$ and $1.0^{*} 10^{-2} ; 3$ ring-critical points $\rho(\mathrm{r})=6.1 * 10^{-3}, 5.4^{*} 10^{-3}$, $5.1 * 10^{-3}$ and 2 cage-critical points $\rho(\mathrm{r})=4.7 * 10^{-3}$ and $\left.5.0^{*} 10^{-3}\right)$. The electronic density $\rho(\mathrm{r})$ values suggested the presence of orienting intramolecular bonding and corresponded to typical aromatic non-covalent interactions. ${ }^{36,37}$ These conclusions were experimentally supported by XRD analysis (Figure 1).

It should be noted that the structure of 5a, derived by the MP2 method, corresponded best with the SAR data.

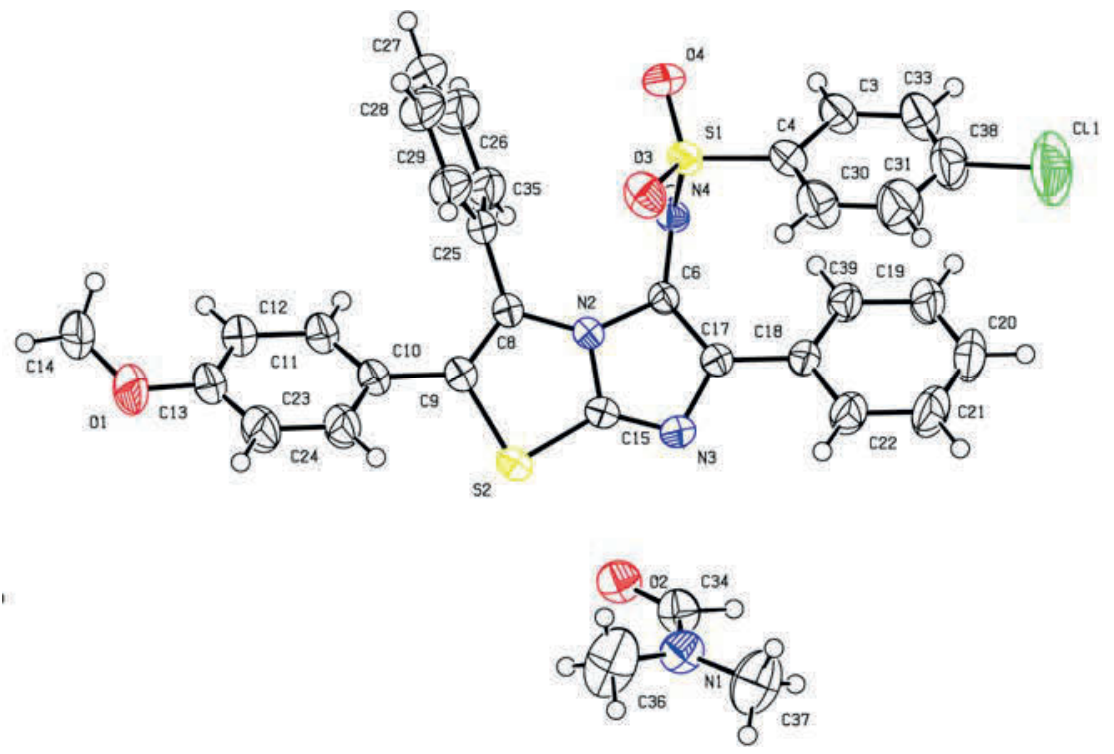

Figure 1. Thermal ellipsoid plot for compound $\mathbf{5 a}$ (50\% probability contours).

The structure of imidazo[2,1- $b]$ thiazole 5a was unequivocally supported by single crystal Xray crystallographic analysis (Fig. 1) and confirmed our conclusions from the spectroscopic data. In the crystal structure of 5a, the molecule associated with a solvent molecule. The benzene ring in the position 6 and the aromatic ring of arylsulfonyl group were substantially parallel, and the distance between them at $3.53 \AA$ indicated intramolecular $\pi$-stacking between the aromatic fragments.

For molecules of $\mathbf{5}$ and $\mathbf{6}$ or their amide anions, the calculation of charge distribution obtained by AIM showed that C-3 carbon atom has a moderate positive charge $(\sim+0.4$ and $\sim+0.5$ for neutral molecules and sulfonamide anions, correspondingly). This data could suggest the reaction path including possible nucleophilic attack of hydroxyl anion on C-3 atom of imidazothiazole ring followed by the Dimroth rearrangement (Scheme 8). At the same time, the 
reaction path, presented in the scheme 8 , is not proved to the full extent. Although Dimroth type isomerization is described for a range of heterocyclic compounds, ${ }^{38}$ similar transformations are not typical for 1,3-thiazole fragments. Therefore, further investigation of a possible reaction path is needed.

\section{Experimental Section}

General. Compound 3a was synthesized according to the previously developed method. ${ }^{30}{ }^{1} \mathrm{H}$, ${ }^{13} \mathrm{C}$ NMR spectra were recorded on a Bruker DPX-400 spectrometer $(400.61,100.13 \mathrm{MHz}$, respectively) with TMS as an internal standard. IR spectra were recorded on a Bruker IFS-25 instrument on $\mathrm{KBr}$ discs. Crystal data were collected on a Bruker D8 Venture diffractometer with $\mathrm{MoK}_{\alpha}$ radiation $(\lambda=0.71073)$ using the $\theta$ and $\omega$ scans. The structure was solved and refined by direct methods using the SHELX program. ${ }^{39}$ Data were corrected for absorption effects using the multi-scan method (SADABS). Non-hydrogen atoms were refined anisotropically using SHELX. ${ }^{39}$ For details of the data collection and the structure solution and refinement, see Supplementary data. CCDC 996956 contains the supplementary crystallographic data for this paper. These data can be obtained free of charge from the Cambridge Crystallographic Data Centre via www.ccdc.cam.ac.uk/data_request/cif.

4-Chloro- $\mathrm{N}$-\{2,2-dichloro-1-[4-(methoxy)phenyl]-2-phenylethyl\}benzenesulfonamide (2a). Imine $1(3.63 \mathrm{~g}, 10 \mathrm{mmol})$, anisole $(5 \mathrm{~mL})$, and $\mathrm{CHCl}_{3}(15 \mathrm{~mL})$ were stirred in the presence of concentrated sulfuric acid $(0.3 \mathrm{~mL})$ and $\mathrm{P}_{4} \mathrm{O}_{10}(0.36 \mathrm{~g})$ for $3 \mathrm{~h}$. The excess of anisole and $\mathrm{CHCl}_{3}$ was evaporated. Then aqueous ammonia solution $(30 \%, 15 \mathrm{~mL})$ was carefully added to the acidic residue. The reaction mass was mixed and the precipitate obtained was filtered off, washed with water, dried and recrystallized. Colorless plates, yield $4.38 \mathrm{~g}, 93 \%, \mathrm{mp} 91-92{ }^{\circ} \mathrm{C}$ (from benzene); IR $\left(v_{\max }, \mathrm{cm}^{-1}\right): 1160,1320\left(\mathrm{SO}_{2}\right), 3240(\mathrm{NH}) \mathrm{cm}^{-1} .{ }^{1} \mathrm{H}$ NMR $\left(400.61 \mathrm{MHz}, \mathrm{DMSO}-d_{6}\right): \delta 3.69$ $(3 \mathrm{H}, \mathrm{s}), 5.45\left(1 \mathrm{H}, \mathrm{d}^{3} J_{\mathrm{CHNH}} 9.5 \mathrm{~Hz}\right), 6.68-6.74(2 \mathrm{H}, \mathrm{m}), 6.94-6.97(4 \mathrm{H}, \mathrm{m}), 7.03-7.07$ (2H, m), 7.10-7.14 (1H, m), 7.34-7.40 (2H, m), 7.55-7.61 (2H, m), 8.89 (1H, d, $\left.{ }^{3} J_{\text {CHNH }} 9.5 \mathrm{~Hz}\right) .{ }^{13} \mathrm{C}$ NMR $\left(100.13 \mathrm{MHz}, \mathrm{DMSO}-d_{6}\right): \delta 55.1,79.9,91.1$ 113.7, 126.8, 128.1, 128.4, 129.1, 130.2, 130.3, 131.1, 131.9, 135.5, 140.0, 159.1. Anal. Calcd. for $\mathrm{C}_{21} \mathrm{H}_{18} \mathrm{Cl}_{3} \mathrm{NO}_{3} \mathrm{~S}$ (471): C, 53.58; $\mathrm{H}, 3.85$; N, 2.98; S 6.81\%. Found: C, 52.96; H, 3.83; N, 2.91; S, 6.78\%.

4-Chloro- $\boldsymbol{N}$-\{2,2-dichloro-1-[4-(methylsulfanyl)phenyl]-2-phenylethyl\}benzenesulfonamide

(2b). Compound 2b was obtained according to the above method from imine 1 (3.63 g, 10 $\mathrm{mmol}$ ) and thioanisole $(5 \mathrm{~mL})$. The reaction time was $5 \mathrm{~h}$. Colorless plates, yield $4.48 \mathrm{~g}, 92 \%$, $\mathrm{mp} 115-117{ }^{\circ} \mathrm{C}$ (from benzene); IR $\left(v_{\max }, \mathrm{cm}^{-1}\right): 1167,1344\left(\mathrm{SO}_{2}\right), 3200(\mathrm{NH}) \mathrm{cm}^{-1} .{ }^{1} \mathrm{H}$ NMR (400.61 MHz, DMSO- $\left.d_{6}\right): \delta 2.37(3 \mathrm{H}, \mathrm{s}), 5.16\left(1 \mathrm{H}, \mathrm{d}^{3} J_{\mathrm{CHNH}} 9.6 \mathrm{~Hz}\right), 6.81-6.85(2 \mathrm{H}, \mathrm{m}), 6.95-$ $6.96(2 \mathrm{H}, \mathrm{m}), 7.25-7.28(2 \mathrm{H}, \mathrm{m}), 7.30-7.33(1 \mathrm{H}, \mathrm{m}), 7.35-7.39(2 \mathrm{H}, \mathrm{m}), 7.42-7.46(2 \mathrm{H}, \mathrm{m}), 7.58-$ $7.64(2 \mathrm{H}, \mathrm{m}), 8.86\left(1 \mathrm{H}, \mathrm{d},{ }^{3} J_{\mathrm{CHNH}} 9.6 \mathrm{~Hz}\right) .{ }^{13} \mathrm{C}$ NMR (100.13 MHz, DMSO-d 6$): \delta$ 15.8, 72.4, $98.4,126.0,127.3,128.2,128.5,128.7,129.7,129.9,130.3,131.5,137.25$ 137.33, 138.4. Anal. 
Calcd. for $\mathrm{C}_{21} \mathrm{H}_{18} \mathrm{Cl}_{3} \mathrm{NO}_{2} \mathrm{~S}_{2}$ (487): C, 51.81; H, 3.73; N, 2.88; S 13.17\%. Found: C, 52.06; H, $3.75 ; \mathrm{N}, 2.71 ; \mathrm{S}, 13.48 \%$.

Synthesis of 5-[4-(methylsulfanyl)phenyl]-4-phenyl-1,3-thiazol-2-amine (3b). The compound 2b $(0.97 \mathrm{~g}, 2 \mathrm{mmol})$, thiourea $(0.76 \mathrm{~g}, 10 \mathrm{mmol})$ and $\mathrm{Na}_{2} \mathrm{CO}_{3}(0.85 \mathrm{~g}, 8 \mathrm{mmol})$ were stirred at $100{ }^{\circ} \mathrm{C}$ for $5 \mathrm{~h}$ in DMF $(15 \mathrm{~mL})$. The reaction mixture was poured into water $(30-40 \mathrm{~mL})$, the precipitate was separated, dried, washed with $10 \%$ aqueous ammonia solution (50 $\mathrm{mL})$. Colorless powder, yield $0.51 \mathrm{~g}, 87 \%, \mathrm{mp} 93-94{ }^{\circ} \mathrm{C}$ (precipitate); IR $\left(v_{\max }, \mathrm{cm}^{-1}\right): 1631(\mathrm{C}=\mathrm{N})$, 3409-3275 $(\mathrm{NH}) \mathrm{cm}^{-1} .{ }^{1} \mathrm{H}$ NMR (400.61 MHz, DMSO- $\left.d_{6}\right): \delta 2.44(3 \mathrm{H}, \mathrm{s}), 7.11-7.17(6 \mathrm{H}, \mathrm{m})$, 7.22-7.28 (3H, m), 7.37-7.41 (2H, m). ${ }^{13} \mathrm{C}$ NMR (100.13 MHz, DMSO- $\left.d_{6}\right): \delta 14.4,118.6,125.9$, 127.2, 128.0, 128.4, 129.1, 129.3, 135.4, 136.9, 144.8, 165.9. Anal. Calcd. for $\mathrm{C}_{16} \mathrm{H}_{14} \mathrm{~N}_{2} \mathrm{~S}_{2}(298)$ : C, 64.39; H, 4.73; N, 9.39; S 21.49\%. Found: C, 63.72; H, 4.62; N, 9.41; S, 21.58\%.

General procedure for the synthesis of adducts 4a,b. Imine 1 (0.72 g, $2 \mathrm{mmol})$ and aminothiazole $2 \mathbf{a}(0.50 \mathrm{~g}, 2 \mathrm{mmol})$ were stirred in 1,4-dioxane $(10 \mathrm{~mL})$ at r.t. for $4 \mathrm{~h}$. Then the reaction mass was mixed with water $(50 \mathrm{~mL})$, the precipitate was filtered off, washed with ether and dried.

\section{4-Chloro- $\mathrm{N}$-\{2,2-dichloro-1-[5-(4-methoxyphenyl)-4-phenyl-1,3-thiazol-2-ylamino]-2-}

phenylethyl benzenesulfonamide (4a). Colorless powder, yield $1.00 \mathrm{~g}, 86 \%, \mathrm{mp} 142-144{ }^{\circ} \mathrm{C}$ (precipitate); IR $\left(v_{\max }, \mathrm{cm}^{-1}\right): 1163,1339\left(\mathrm{SO}_{2}\right), 1610(\mathrm{C}=\mathrm{N}), 3382-3238(\mathrm{NH}) \mathrm{cm}^{-1} .{ }^{1} \mathrm{H}$ NMR (400.61 MHz, DMSO- $\left.d_{6}\right): \delta 3.74(3 \mathrm{H}, \mathrm{s}), 6.48\left(1 \mathrm{H}, \mathrm{dd},{ }^{3} J_{\mathrm{CHNH}} 9.5 \mathrm{~Hz},{ }^{3} J_{\mathrm{CHNH}} 9.6 \mathrm{~Hz}\right), 6.81-6.94$ $(2 \mathrm{H}, \mathrm{m}), 7.03-7.15(2 \mathrm{H}, \mathrm{m}), 7.27-7.44(10 \mathrm{H}, \mathrm{m}), 7.60-7.68(2 \mathrm{H}, \mathrm{m}), 7.73-7.83(2 \mathrm{H}, \mathrm{m}), 8.17(1 \mathrm{H}$, $\left.\mathrm{d},{ }^{3} J_{\mathrm{CHNH}} 9.5 \mathrm{~Hz}\right), 8.93\left(1 \mathrm{H}, \mathrm{d},{ }^{3} J_{\mathrm{CHNH}} 9.6 \mathrm{~Hz}\right) .{ }^{13} \mathrm{C}$ NMR $\left(100.13 \mathrm{MHz}, \mathrm{DMSO}-d_{6}\right): \delta 55.0,71.2$, $94.5,102.7,114.1,124.2,126.9,127.0,127.9,128.0,128.1,128.2,129.1,129.3,130.4,135.1$, 136.8, 139.1, 140.0, 142.4, 158.6, 162.8. Anal. Calcd. for $\mathrm{C}_{30} \mathrm{H}_{24} \mathrm{Cl}_{3} \mathrm{~N}_{3} \mathrm{O}_{3} \mathrm{~S}_{2}$ (645): C, 55.86; $\mathrm{H}$, 3.75; N, 6.51; S, 9.94\%. Found: C, 54.56; H, 3.69; N, 6.58; S, 9.52\%.

4-Chloro- $\boldsymbol{N}$-\{2,2-dichloro-1-[5-(4-(methylsulfanyl)phenyl)-4-phenyl-1,3-thiazol-2-ylamino]2-phenylethyl \}benzenesulfonamide (4b). Yellow powder, yield $0.97 \mathrm{~g}, 82 \%$, mp 91-93 ${ }^{\circ} \mathrm{C}$ (precipitate); IR $\left(v_{\max }, \mathrm{cm}^{-1}\right): 1168,1342\left(\mathrm{SO}_{2}\right), 1586(\mathrm{C}=\mathrm{N}), 3247-3292(\mathrm{NH}) \mathrm{cm}^{-1} .{ }^{1} \mathrm{H}$ NMR $\left(400.61 \mathrm{MHz}, \mathrm{DMSO}-d_{6}\right): \delta 2.45(3 \mathrm{H}, \mathrm{s}), 6.46\left(1 \mathrm{H}, \mathrm{dd},{ }^{3} J_{\mathrm{CHNH}} 9.5 \mathrm{~Hz},{ }^{3} J_{\mathrm{CHNH}} 9.8 \mathrm{~Hz}\right), 7.06-7.12$ $(2 \mathrm{H}, \mathrm{m}), 7.15-7.21(2 \mathrm{H}, \mathrm{m}), 7.27-7.47(9 \mathrm{H}, \mathrm{m}), 7.64-7.67(2 \mathrm{H}, \mathrm{m}), 7.78-7.84(3 \mathrm{H}, \mathrm{m}), 8.24(1 \mathrm{H}$, d, $\left.{ }^{3} J_{\mathrm{CHNH}} 9.5 \mathrm{~Hz}\right), 8.95\left(1 \mathrm{H}, \mathrm{d},{ }^{3} J_{\mathrm{CHNH}} 9.8 \mathrm{~Hz}\right) .{ }^{13} \mathrm{C}$ NMR $(100.13 \mathrm{MHz}$, DMSO-d 6 ): $\delta 14.4,71.3$, $94.5,120.4,125.8,126.9,127.3,127.6,128.0,128.1,128.2,128.3,128.6,129.0,129.5,134.9$, 136.9, 137.5, 139.1, 140.0, 143.1, 163.2. Anal. Calcd. for $\mathrm{C}_{30} \mathrm{H}_{24} \mathrm{Cl}_{3} \mathrm{~N}_{3} \mathrm{O}_{2} \mathrm{~S}_{3}$ (661): C, 54.5; $\mathrm{H}$, 3.66; N, 6.36; S, 14.55\%. Found: C, 53.6; H, 3.59; N, 6.28; S, 14.63\%.

\section{General procedure for the synthesis of imidazo[2,1-b][1,3]thiazols 5a,b.}

Method A. Compound 4a or $4 \mathbf{b}(1 \mathrm{mmol})$ and $\mathrm{NaOH}(0.15 \mathrm{~g}, 3.5 \mathrm{mmol})$ were stirred in 1,4dioxane $(10 \mathrm{~mL})$ for $5 \mathrm{~h}$. The reaction mass was mixed with water $(30 \mathrm{~mL})$ and $10 \%$ hydrochloric acid was added to neutralize it. The precipitate was filtered off, dried and washed with ether. 
Method B. Imine 1 (0.72 g, $2 \mathrm{mmol})$, aminothiazole 3a or $\mathbf{3 b}(2 \mathrm{mmol})$ were stirred in 1,4dioxane $(10 \mathrm{~mL})$ for $4 \mathrm{~h}$. Then $\mathrm{NaOH}(0.29 \mathrm{~g}, 7.2 \mathrm{mmol})$ and 1.4-dioxane $(10 \mathrm{~mL})$ were added and the reaction mixture was stirred for $5 \mathrm{~h}$. The reaction mass was mixed with water $(50 \mathrm{~mL})$ and $10 \%$ hydrochloric acid was added to neutralize it. The precipitate was filtered off, dried and washed with ether.

\section{4-Chloro- $N$-[2-(4-methoxyphenyl)-3,6-diphenylimidazo[2,1-b][1,3] thiazol-5-yl]benzene-}

sulfonamide (5a). Coloress powder, yield $0.43 \mathrm{~g}, 75 \%$ (method A) and $0.65 \mathrm{~g}, 63 \%$ (method B), mp 194-196 ${ }^{\circ} \mathrm{C}$ (precipitate); IR $\left(v_{\max }, \mathrm{cm}^{-1}\right): 1172,1342\left(\mathrm{SO}_{2}\right), 1601(\mathrm{C}=\mathrm{N}) \mathrm{cm}^{-1}$. ${ }^{1} \mathrm{H}$ NMR (400.61 MHz, DMSO- $\left.d_{6}\right): \delta 3.73(3 \mathrm{H}, \mathrm{s}), 6.84-6.90(2 \mathrm{H}, \mathrm{m}), 7.15-7.20(4 \mathrm{H}, \mathrm{m}), 7.38-7.46(7 \mathrm{H}$, m), 6.99-7.08 (5H, m), $10.08(1 \mathrm{H}, \mathrm{s}) .{ }^{13} \mathrm{C}$ NMR (100.13 MHz, DMSO- $\left.d_{6}\right): \delta 56.5,114.4,115.8$, 115.9 , 123.2, 125.3, 126.6, 127.8, 128.1, 128.27, 128.29, 128.4, 128.7, 129.3, 130.5, 131.6, 132.7, 137.6, 139.4, 141.9, 145.3 159.5. Anal. Calcd. for $\mathrm{C}_{30} \mathrm{H}_{22} \mathrm{ClN}_{3} \mathrm{O}_{3} \mathrm{~S}_{2}$ (572): C, 62.98; $\mathrm{H}$, 3.88; N, 7.34; S, 11.21\%. Found: C, 61.30; H, 3.81; N, 7.23; S, 11.32\%.

4-Chloro- $N$ - $\{$ 2-[4-(methylsulfanyl)phenyl]-3,6-diphenylimidazo[2,1-b][1,3]thiazol-5yl benzenesulfonamide (5b). Yellow powder, yield $0.41 \mathrm{~g}, 70 \%(\operatorname{method} \mathrm{A})$ and $0.65 \mathrm{~g}, 61 \%$ (method B), mp 188-190 ${ }^{\circ} \mathrm{C}$ (precipitate); IR ( $\left.v_{\max }, \mathrm{cm}^{-1}\right)$ : 1162, $1339\left(\mathrm{SO}_{2}\right), 1596(\mathrm{C}=\mathrm{N}) \mathrm{cm}^{-1}$. ${ }^{1} \mathrm{H}$ NMR (400.61 MHz, DMSO- $\left.d_{6}\right): \delta 2.44(3 \mathrm{H}, \mathrm{s}), 6.99-7.08(5 \mathrm{H}, \mathrm{m}), 7.13-7.20(7 \mathrm{H}, \mathrm{m}), 7.35-$ $7.40(2 \mathrm{H}, \mathrm{m}), 7.44-7.52(4 \mathrm{H}, \mathrm{m}), 10.10(1 \mathrm{H}, \mathrm{s}) .{ }^{13} \mathrm{C}$ NMR $\left(100.13 \mathrm{MHz}, \mathrm{DMSO}-d_{6}\right): \delta 14.2$, $114.2,115.9,124.9,125.7,126.6,127.2,127.8,127.9,128.1,128.3,128.7,128.8,129.4,131.45$, 131.47, 132.6, 137.5, 139.3, 139.4, 141.9, 145.2. Anal. Calcd. for $\mathrm{C}_{30} \mathrm{H}_{22} \mathrm{ClN}_{3} \mathrm{O}_{2} \mathrm{~S}_{3}$ (588): C, 61.26; H, 3.77; N, 7.14; S 16.36\%. Found: C, 60.06; H, 3.72; N, 7.09; S, 16.45\%.

\section{Acknowledgements}

Spectroscopic and analytical data were obtained using instrumentation in the Baykal Analytical Center for Collective Use SB RAS.

\section{References}

1. Levkovskaya, G. G.; Drozdova, T. I.; Rozentsveig, I. B.; Mirskova, A. N. Russ. Chem. Rev. 1999, 68, 581-604. http://dx.doi.org/10.1070/RC1999v068n07ABEH000476

2. De Kimpe, N.; Verhé, R. $\alpha$-Haloaldehydes and $\alpha$-Haloimines; J. Wiley \& Sons Inc.: Chichester; 1988, p 460.

3. De Kimpe, N.; Verhé, R.; De Buyck, L.; Schamp, N. Org. Prep. Proced. Int. 1980, 12, 49180.

http://dx.doi.org/10.1080/00304948009355422

4. Mangelinckx, S.; Giubellina, N.; De Kimpe, N. Chem. Rev. 2004, 104, 2353-2400. 
http://dx.doi.org/10.1021/cr020084p

5. Rozentsveig, I. B.; Levkovskaya, G. G.; Albanov, A. I.; Mirskova, A. N. Russ. J. Org. Chem. 2000, 36, 671-673.

6. Kondrashov, E. V.; Rozentsveig, I. B.; Levkovskaya, G. G.; Mirskova, A. N. Mendeleev Commun. 2003, 13, 25-26.

http://dx.doi.org/10.1070/MC2003v013n01ABEH001569

7. Rozentsveig, I. B.; Levkovskaya, G. G.; Rozentsveig, G. N.; Mirskova, A. N.; Krivdin, L. B.; Larina, L. I.; Albanov, A. I. Tetrahedron Lett. 2005, 46, 8889-8893.

http://dx.doi.org/10.1016/j.tetlet.2005.10.079

8. Rozentsveig, I. B.; Popov, A. V.; Rozentsveig, G. N.; Serykh, V. Y.; Chernyshev, K. A.; Krivdin, L. B.; Levkovskaya, G. G. Mol. Diversity 2010, 14, 533-541.

http://dx.doi.org/10.1007/s11030-010-9231-z

9. Mirskova, A. N.; Rudyakova, E. V.; Rozentsveig, I. B.; Stupina, A. G.; Levkovskaya, G. G.; Albanov, A. I. Pharm. Chem. J. 2001, 35, 21-24. http://dx.doi.org/10.1023/A\%3A1012341604254

10. Rozentsveig, I. B.; Rozentsveig, G. N.; Serykh, V. Yu.; Chernyshev, K. A.; Levkovskaya, G. G. Eur. J. Org. Chem. 2011, 4415-4421. http://dx.doi.org/10.1002/ejoc.201100362

11. Rozentsveig, I. B.; Serykh, V. Y.; Chernysheva, G. N.; Chernyshev, K. A.; Kondrashov, E. V.; Tretyakov, E. V.; Romanenko, G. V. Eur. J. Org. Chem. 2013, 368-375.

http://dx.doi.org/10.1002/ejoc.201201006

12. Rozentsveig, I. B.; Serykh, V. Yu.; Chernysheva, G. N.; Kondrashov, E. V.; Fedotova, A. I.; Ushakov, I. A.; Tretyakov, E. V.; Romanenko, G. V. Eur. J. Org. Chem. 2014, 6547-6557. http://dx.doi.org/10.1002/ejoc.201402695

13. Krivdin, L. B.; Chernyshev, K. A.; Rosentsveig, G. N.; Ushakova, I. V.; Rosentsveig, I. B.; Levkovskaya, G. G. Magn. Reson. Chem. 2007, 45, 980-984.

http://dx.doi.org/10.1002/mrc.2070

14. Rozentsveig, I. B.; Rozentsveig, G. N.; Mirskova, A. N.; Chernyshev, K. A.; Krivdin, L. B.; Levkovskaya, G. G. Russ. J. Gen. Chem. 2008, 78, 1371-1379.

http://dx.doi.org/10.1134/S1070363208070141

15. Andreani, A.; Burnelli, S.; Granaiola, M.; Guardigli, M.; Leoni, A.; Locatelli, A.; Morigi, R.; Rambaldi, M.; Rizzoli, M.; Varoli, L.; Roda, A. Eur. J. Med. Chem. 2008, 43, 657-661. http://dx.doi.org/10.1016/j.ejmech.2007.04.018

16. Borhani, D. W.; Calderwood, D. J.; Frank, K. E.; Davis, H. M.; Josephsohn, N. S.; Skinner, B. S. WO Pat. 2008/063287, 29 May 2008.

17. Emmitte, K. A.; Wilson, B. J.; Baum, E. W.; Emerson, H. K.; Kuntz, K. W.; Nailor, K. E.; Salovich, J. M.; Smith, S. C.; Cheung, M.; Gerding, R. M.; Stevens, K. L.; Uehling, D. E.; Mook, R. A., Jr.; Moorthy, G. S.; Dickerson, S. H.; Hassell, A. M.; Leesnitzer, M. A.; Shewchuk, L. M.; Groy, A.; Rowand, J. L.; Anderson, K.; Atkins, C. L.; Yang, J.; Sabbatini, P.; Kumar, R. Bioorg. Med. Chem. Lett. 2009, 19, 1004-1007. 
http://dx.doi.org/10.1016/j.bmcl.2009.12.056

18. Fidanze, S. D.; Erickson, S. A.; Wang, G. T.; Mantei, R.; Clark, R. F.; Sorensen, B. K.; Bamaung, N. Y.; Kovar, P.; Johnson, E. F.; Swinger, K. K.; Stewart, K. D.; Zhang, Q.; Tucker, L. A.; Pappano, W. N.; Wilsbacher, J. L.; Wang, J.; Sheppard, G. S.; Bell, R. L.; Davidsen, S. K.; Hubbard, R. D. Bioorg. Med. Chem. Lett. 2010, 20, 2452-2455.

http://dx.doi.org/10.1016/j.bmcl.2010.03.015

19. Andreani, A.; Rambaldi, M.; Mascellani, G.; Rugarli, P. Eur. J. Med. Chem. 1987, 22, 19-22. http://dx.doi.org/10.1016/0223-5234(87)90169-3

20. Andreani, A.; Rambaldi, M.; Andreani, F.; Bossa, R.; Galatulas, I. Eur. J. Med. Chem. 1988, $23,385-389$.

http://dx.doi.org/10.1016/0223-5234(88)90214-0

21. Andreani, A.; Rambaldi, M.; Locatelli, A.; Bossa, R.; Fraccari, A.; Galatulas, I. Pharm. Acta Helv. 1993, 68, 21-24.

http://dx.doi.org/10.1016/0031-6865(93)90004-P

22. Andreani, A.; Bonazzi, D.; Rambaldi, M. Arch. Pharm. 1982, 315, 451-456. http://dx.doi.org/10.1002/ardp.19823150511

23. Andreani, A.; Rambaldi, M.; Locatelli, A.; Bossa, R.; Fraccari, A.; Galatulas, I. J. Med. Chem. 1992, 35, 4634-4637.

http://dx.doi.org/10.1021/jm00102a018

24. Poorrajab, F.; Ardestani, S. K.; Emami, S.; Behrouzi-Fardmoghaddam, M.; Shafiee, A.; Foroumadi, A. Eur. J. Med. Chem. 2009, 44, 1758-1762.

http://dx.doi.org/10.1016/j.ejmech.2008.03.039

25. Khalaj, A.; Nakhjiri, M.; Negahbani, A. S.; Samadizadeh, M.; Firoozpour, L.; Rajabalian, S.; Samadi, N.; Faramarzi, M. A.; Adipour, N.; Shafiee, A.; Foroumadi, A. Eur. J. Med. Chem. 2011, 46, 65-70.

http://dx.doi.org/10.1016/j.ejmech.2010.10.015

26. Gupta, G. D.; Jain, K. K.; Gupta, R. P.; Pujari, H. K. Indian J. Chem., Sect. B: Org. Chem. Incl. Med. Chem. 1983, 22, 268.

27. Amarouch, H.; Loiseau, P. R.; Bacha, C.; Caujolle, R.; Payard, M.; Loiseau, P. M.; Bories, C.; Gayral, P. Eur. J. Med. Chem. 1987, 22, 463-466.

http://dx.doi.org/10.1016/0223-5234(87)90037-7

28. Mohamed, H. A.; Abdel-Wahab, B. F. J. Sulfur Chem. 2012, 33, 589-604. http://dx.doi.org/10.1080/17415993.2012.695792

29. Mahdavi, M.; Asadi, M.; Saeedi, M.; Ebrahimi, M.; Rasouli, M. A.; Ranjbar, P. R.; Foroumadi, A.; Shafiee, A. Synthesis 2012, 44, 3649-3654. http://dx.doi.org/10.1055/s-0032-1317515

30. Rozentsveig, G. N.; Serykh, V. Y.; Chernyshev, K. A.; Rozentsveig, I. B.; Levkovskaya, G. G.; Krivdin, L. B. Russ. J. Org. Chem. 2011, 47, 572-576. http://dx.doi.org/10.1134/S1070428011040178

31. Granovsky A. A. Firefly version 8. 
http://classic.chem.msu.su/gran/firefly/index.html

32. Schmidt, M. W.; Baldridge, K. K.; Boatz, J. A.; Elbert, S. T.; Gordon, M. S.; Jensen, J. H.; Koseki, S.; Matsunaga, N.; Nguyen, K. A.; Su, S.; Windus, T. L.; Dupuis, M.; Montgomery, J. A. J. Comput. Chem. 1993, 14, 1347-1363.

http://dx.doi.org/10.1002/jcc.540141112

33. Frisch, M. J.; Trucks, G. W.; Schlegel, H. B.; Scuseria, G. E.; Robb, M. A.; Cheeseman, J. R.; Scalmani, G.; Barone, V.; Mennucci, B.; Petersson, G. A.; Nakatsuji, H.; Caricato, M.; Li, X.; Hratchian, H. P.; Izmaylov, A. F.; Bloino, J.; Zheng, G.; Sonnenberg, J. L.; Hada, M.; Ehara, M.; Toyota, K.; Fukuda, R.; Hasegawa, J.; Ishida, M.; Nakajima, T.; Honda, Y.; Kitao, O.; Nakai, H.; Vreven, T.; Montgomery, J. A.; Peralta, Jr. J. E.; Ogliaro, F.; Bearpark, M.; Heyd, J. J.; Brothers, E.; Kudin, K. N.; Staroverov, V. N.; Kobayashi, R.; Normand, J.; Raghavachari, K.; Rendell, A.; Burant, J. C.; Iyengar, S. S.; Tomasi, J.; Cossi, M.; Rega, N.; Millam, J. M.; Klene, M.; Knox, J. E.; Cross, J. B.; Bakken, V.; Adamo, C.; Jaramillo, J.; Gomperts, R.; Stratmann, R. E.; Yazyev, O.; Austin, A. J.; Cammi, R.; Pomelli, C.; Ochterski, J. W.; Martin, R. L.; Morokuma, K.; Zakrzewski, V. G.; Voth, G. A.; Salvador, P.; Dannenberg, J. J.; Dapprich, S.; Daniels, A. D.; Farkas, Ö.; Foresman, J. B.; Ortiz, J. V.; Cioslowski, J.; Fox, D. J. Gaussian 09, Revision C.01, Gaussian, Inc., Wallingford CT, 2009.

34. Keith, T. A. AIMAll (Version 15.05.18). TK Gristmill Software, Overland Park KS, USA, 2015 (aim.tkgristmill.com)

35. Bader, R. F. W. Atoms in Molecules A Quantum Theory, Oxford University Press:Oxford, 1990.

36. Kelly, B.; Sánchez-Sanz, G.; Blanco, F.; Rozas, I. Comput. Theor. Chem. 2012, 998, 64-73. http://dx.doi.org/10.1016/j.comptc.2012.06.004

37. Suresh, C. H.; Mohan, N.; Vijayalakshmi, K. P.; George, R.; Mathew, J. M. J. Comput. Chem. 2009, 30, 1392-1404.

http://dx.doi.org/10.1002/jcc.21162

38. El Ashry, E. S. H.; Nadeem, S.; Shah, M. R.; El Kilany, Y. Adv. Heterocycl. Chem. 2010, 101, 161-228.

http://dx.doi.org/10.1016/S0065-2725(10)01005-6

39. Sheldrick, G. M. Acta Crystallogr. 2008, 64, 112-122.

http://dx.doi.org/10.1107/S0108767307043930 